\title{
Peningkatan Literasi Masyarakat terhadap Orang Dengan Skizofrenia (ODS) di Desa Sindumartani Yogyakarta
}

\author{
Abdur Rafik ${ }^{1 *}$, Yosi Febrianti², Novyan Lusiyana ${ }^{3}$ \\ ${ }^{1}$ Fakultas Ekonomi, Universitas Islam Indonesia \\ ${ }^{2}$ Fakultas Matematika dan Ilmu Pengetahuan Alam, Universitas Islam Indonesia \\ ${ }^{3}$ Fakultas Kedokteran, Universitas Islam Indonesia \\ *Corresponding Email: abdurrafik@uii.ac.id
}

\begin{abstract}
ABSTRAK
Hasil Riset Kesehatan Dasar (RISKESDAS) Kementerian Kesehatan Republik Indonesia menempatkan Yogyakarta sebagai salah satu provinsi dengan prevalensi skizofrenia tertinggi di Indonesia setelah Bali, dan Desa Sindumartani adalah salah satu desa dengan jumlah Orang dengan Skizofrenia (ODS) tertinggi di Yogyakarta. Adanya stigma negatif dari masyarakat dan bahkan anggota keluarga ODS menjadi salah satu penghambat krusial proses penyembuhan ODS. Stigma dan kesadaran sosial yang rendah terhadap ODS disinyalir mmenghambat proses pengembangan kognisi sosial pada ODS. Pengabdian masyarakat ini mencoba melakukan penyuluhan dan edukasi terhadap kelompok masyarakat non-ODS dan anggota keluarga ODS agar mereka dapat terliterasi secara baik akan skizofrenia dengan segala karekteristik dan penanganannya. Selain dengan penyuluhan, edukasi dilakukan dengan membentuk kader siaga sehat jiwa dalam kelompok masyarakat. Dalam kurun waktu setelah pelaksanaan kegiatan, hasil menunjukkan adanya peningkatan literasi masyarakat terhadap skizofrenia dan penurunan prevalensi kekambuhan pada ODS. Untuk meningkatkan kesinambungan hasil, terapi lanjutan dalam bentuk vokasional dianjurkan untuk dilakukan.
\end{abstract}

Kata Kunci: gangguan kejiwaan, literasi sosial, ods, skizofrenia.

\section{ABSTRACT}

The Results of Basic Health Research from Ministry of Health of the Republic in Indonesia places Yogyakarta as one of the provinces with the highest prevalence of schizophrenia after Bali, and Sindumartani Village is one of the villages with the highest number of People with Schizophrenia (PWS) in Yogyakarta. The presence of negative stigma from the community and even family members of PWS is one of the crucial obstacles to the PWS healing process. The stigma and low social awareness towards PWS are thought to hamper the process of enriching ODS' social cognition. Our activities try to provide counseling and education to non-PWS members groups and PWS' family members so that they can be well literated for schizophrenia with all the characteristics and handling. In addition to the counseling, we educate them by forming a healthy mental alert cadre within the community. In the period after the implementation of the activities, the results showed an increase in communities' literacy in schizophrenia and a decrease in the prevalence of recurrence in PWS. To improve the sustainability of results, further therapy such as vocational therapy is recommended.

Keywords: mental illness, schizhoprenia, social literation 


\section{PENDAHULUAN}

Skizofrenia dapat didefinisikan sebagai sebuah gangguan pada otak yang ditandai dengan gangguan proses berfikir berupa waham, delusi, halusinasi, dan atau ilusi. Orang dengan Skizofrenia (ODS) umumnya akan kesulitan membedakan mana yang riil dan mana yang tidak. ODS biasanya akan susah untuk berpikir logis, mengendalikan emosi, dan berhubungan dengan orang lain (Levine dan Levine, 2009). Penyakit ini, jika tidak ditangani dengan baik, dapat menimbulkan kondisi kegawatan yang akut (Awad, 2016; Mcnally, 2016).

Skizofrenia merupakan salah satu jenis gangguan kejiwaan yang banyak diderita di Indonesia (Zahnia dan Sumekar, 2016). Data Riskesdas tahun 2018 mengungkapkan bahwa rerata proporsi nasional rumah tangga yang anggota rumah tangganya menderita gangguan jiwa skizofrenia adalah sebanyak 7\%. Angka ini meningkat secara signifikan dibandingkan tahun 2013 yang hanya berjumlah 1,7\%. Sedangkan proporsi anggota rumah tangga dengan skizofrenia di Daerah Istimewa Yogyakarta (DIY), yaitu sebanyak 10\%. Untuk Indonesia, angka 10\% ini menempatkan DIY sebagai provinsi dengan penderita skizofrenia terbanyak kedua setelah Bali (Badan Penelitian dan Pengembangan Kesehatan Kementerian Kesehatan, 2018).

Desa Sindumartani teridentifikasi sebagai salah satu desa dengan kasus skizofrenia paling tinggi di wilayah Kecamatan Ngemplak, Kabupaten Sleman, DIY. Desa ini memiliki 37 ODS dengan penderita termuda berusia 9 tahun. Angka ini mengalami peningkatan sekitar 27\% jika dibandingkan dengan tahun 2014 yang hanya berjumlah 28 orang. Desa ini memiliki kepadatan penduduk 91 jiwa/Ha dan sebagian besar penduduknya bekerja sebagai dengan rerata tingkat pendidikan lulusan Sekolah Menegah Atas (SMA).

Di tengah masyarakat, kemunculan gejala skizofrenia pada anggota keluarga seringkali dianggap sebagai aib. Akibatnya, ODS acapkali diperlakukan sewenang-wenang seperti dikurung dan bahkan dipasung (Human Rights Watch, 2016). Para anggota keluarga berkecenderungan untuk lebih menyembunyikan dan menjauhkan ODS dari lingkungan sekitar karena dianggap bisa merepotkan dan membuat masalah. Hal ini diperparah dengan adanya persepsi dan stigma negatif terhadap ODS dari anggota masyarakat lainnya (keluarga non-ODS). Padahal, ODS yang memang sedari awal memiliki kesulitan untuk berinteraksi dengan lingkungan sekitarnya seharusnya bisa dibangun kognisi sosialnya melalui bantuan keluarga dan masyarakat (Langdon, Connors dan Connaughton, 2014; Fulford, Campellone dan Gard, 2018; Reddy et al., 2019). Sayangnya, alih-alih membantu memperkuat kognisi sosial ODS, beberapa penelitian malah menunjukkan berbagai perilaku deeskriminatif masyarakat terhadap ODS (Fernando et al., 2017; Li et al., 2017; Krupchanka et al., 2018; Morgades-bamba, Fuster-ruizdeapodaca dan Molero, 2019).

Selain memperlambat penguatan kognisi sosial pada ODS, pengasingan dan perilaku deskriminatif terhadap ODS akan membuat mereka mengalami isolasi sosial yang kemudian akan menjadi pencetus kekambuhan atau berulangnya gejala skizofrenia. Beberapa gejala yang berkaitan dengan kekambuhan di antaranya menarik diri, gangguan mood, ganguan emosional, gangguan kemampuan bicara, dan aktivitas yang melambat.

Oleh karena itu, keluarga dan anggota masyarakat non-ODS seharusnya bisa menjadi salah satu wahana penyembuhan ODS melalui sikap dan perilaku sosial yang tepat. Beberapa penelitian telah membuktikan bahwa dukungan keluarga yang baik dapat menurunkan angka kekambuhan pada ODS (Latipun, 2016; Simanullang, 2018). 
Atas dasar permasalahan di atas, yaitu masih berkembangnya stigma negatif serta perilaku deskriminatif terhadap ODS, baik oleh anggota keluarga ODS maupun anggota non-keluarga ODS, pengabdian masyarakat ini dirancang. Aktivitas pengabdian masyarakat dalam program pengabdian ini berupa penyuluhan dan pembentukan kader siaga sehat jiwa di Desa Sindumartani, Kecamatan Ngemplak, Kabupaten Sleman, DIY. Aktivitas penyuluhan dan pembentukan kader siaga sehat jiwa ini merupakan bagian kecil dari rangkaian aktivitas yang dirancang terintegrasi dalam Program Pengabdian Masyarakat yang dibiayai oleh Dikti. Harapan dari terselenggaranya aktivitas ini adalah meningkatnya pengetahuan masyarakat terhadap skizofrenia sehingga bisa berkontribusi terhadap proses interaksi sosial yang wajar dan adil bagi ODS yang pada gilirannya diharapkan dapat meningkatkan tingkat kesehatan ODS.

\section{METODE}

Ada dua kegiatan utama yang dilaksanakan untuk meningkatkan literasi masyarakat terhadap skizofrenia dan berbagai karakteristiknya. Dua kegiatan tersebut, yaitu; (1) Penyuluhan tentang Skizofrenia terhadap anggota keluarga dan anggota non-keluarga ODS; dan (2) Pembentukan kader siaga sehat jiwa yang berfungsi mensosialisasikan dan melakukan edukasi berkelanjutan terhadap masyarakat terkait ODS.

Penyuluhan bertujuan untuk memberikan edukasi kepada masyarakat tentang skizofrenia dan bagaimana seharusnya mereka bersosialisasi dan berdampingan secara sosial dengan ODS. Penyuluhan dilaksanakan dengan metode training of trainer (TOT), dimana narasumber memberikan ceramah dan diikuti dengan focus group discussion.

Sementara kader siaga sehat jiwa dibentuk dalam rangka meneruskan sosialisasi berkelanjutan pada masyarakat desa tentang apa dan bagaimana skizofrenia. Kader siaga dipilih dari anggota masyarakat di Desa Sindumartani dengan cara seleksi. Beberapa anggota masyarakat yang menghadiri penyuluhan diberikan edukasi dan arahan lebih lanjut dan diuji pengetahuannya berkaitan dengan ODS. Tiga anggota masyarakat dengan nilai tertinggi ditunjuk sebagai kader siaga dan dibekali buku siaga sehat jiwa skizofrenia yang disusun oleh tim.

Kegiatan penyuluhan diselenggarakan di Balai Desa Sindumartani, Kecamatan Ngemplak, Kabupaten Sleman, Daerah Istimewa Yogyakarta (DIY) pada tanggal 10 Juli 2019. Kegiatan dimulai jam 08:00 dan selesai jam 10:00 WIB. Di tahap awal, masyarakat diberikan penyuluhan tentang apa itu ODS, bagaimana gejalagejalanya, dan bagaimana sebaiknya berinteraksi dan memperlakukan mereka di tengah-tengah masyarakat. Peserta yang hadir meliputi masyarakat umum non-ODS sebanyak 10 orang, anggota keluarga ODS sebanyak 15 orang, dan beberapa ODS sendiri. Meskipun jumlah peserta yang hadir tidak sesuai dengan yang diekspektasikan, namun peserta sangat antusias dan mengikuti dengan seksama setiap penjelasan dari narasumber. Beberapa anggota keluarga ODS juga terlibat secara interaktif bertanya dan berkonsultasi dengan narasumber.

Untuk mengukur dampak kegiatan penyuluhan, digunakan pengukuran pre-test dan post-test terhadap literasi peserta kaitannya dengan skizofrenia. Tim membagikan kuesioner terhadap peserta penyuluhan pada 
JAMALI - Volume. 01, Issue. 02, September 2019

saat sebelum kegiatan dilaksanakan dan setelah kegiatan selesai dilaksanakan (dokumentasi kegiatan lihat Gambar 1).

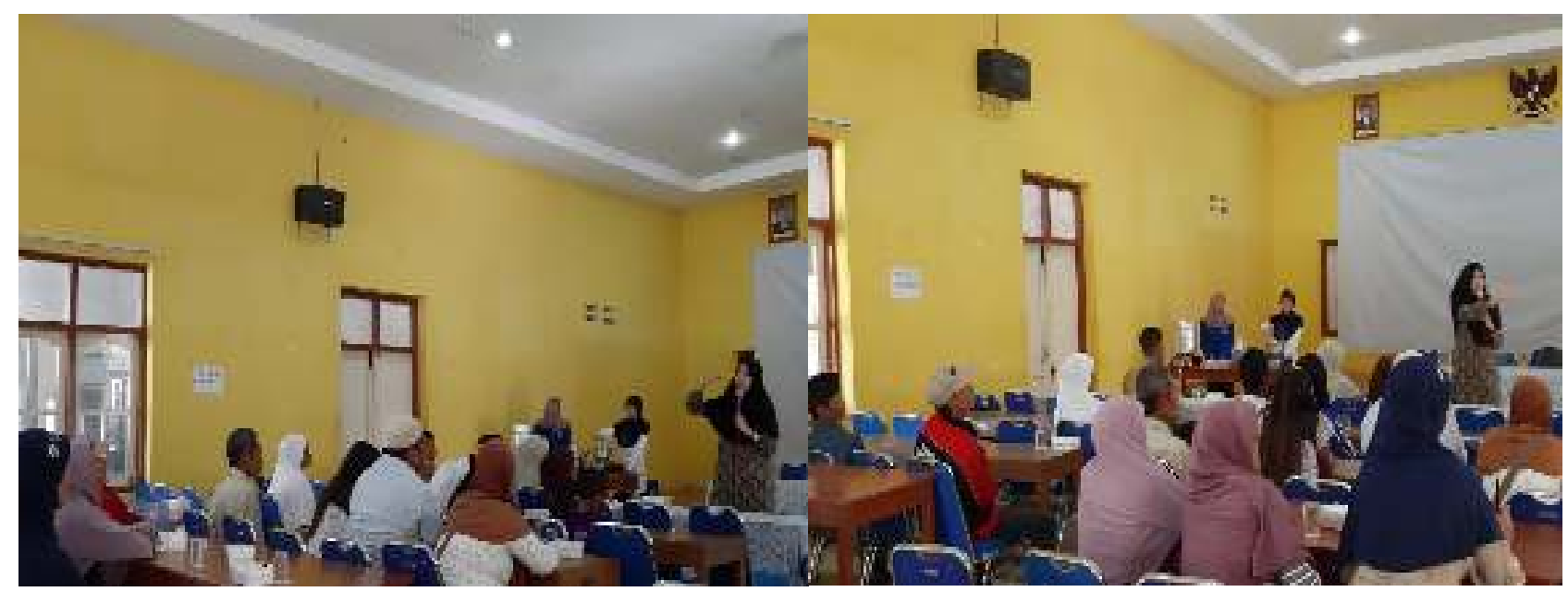

Gambar 1. Kegiatan Penyuluhan skizofrenia

Sementara itu, kegiatan edukasi kader siaga sehat jiwa dilakukan secara face-to face antara kader dengan tim. Edukasi lebih lanjut dan pemilihan perwakilan kader siaga sehat jiwa dilaksanakan pada Rabu, 18 Sepetember 2019 di Balai Desa Sindumartani. Ada 20 puluh kader siaga yang mendapatkan edukasi secara khusus dari tim. Dari 20 kader tersebut, dipilih lima orang sebagai representasi kader dan mereka dibekali buku saku siaga sehat jiwa secara khusus. Buku saku siaga sehat jiwa ini berfungsi sebagai referensi bagi kader dalam mensosialisasikan skizofrenia ke masyarakat (buku siaga sehat jiwa lihat Gambar 2).

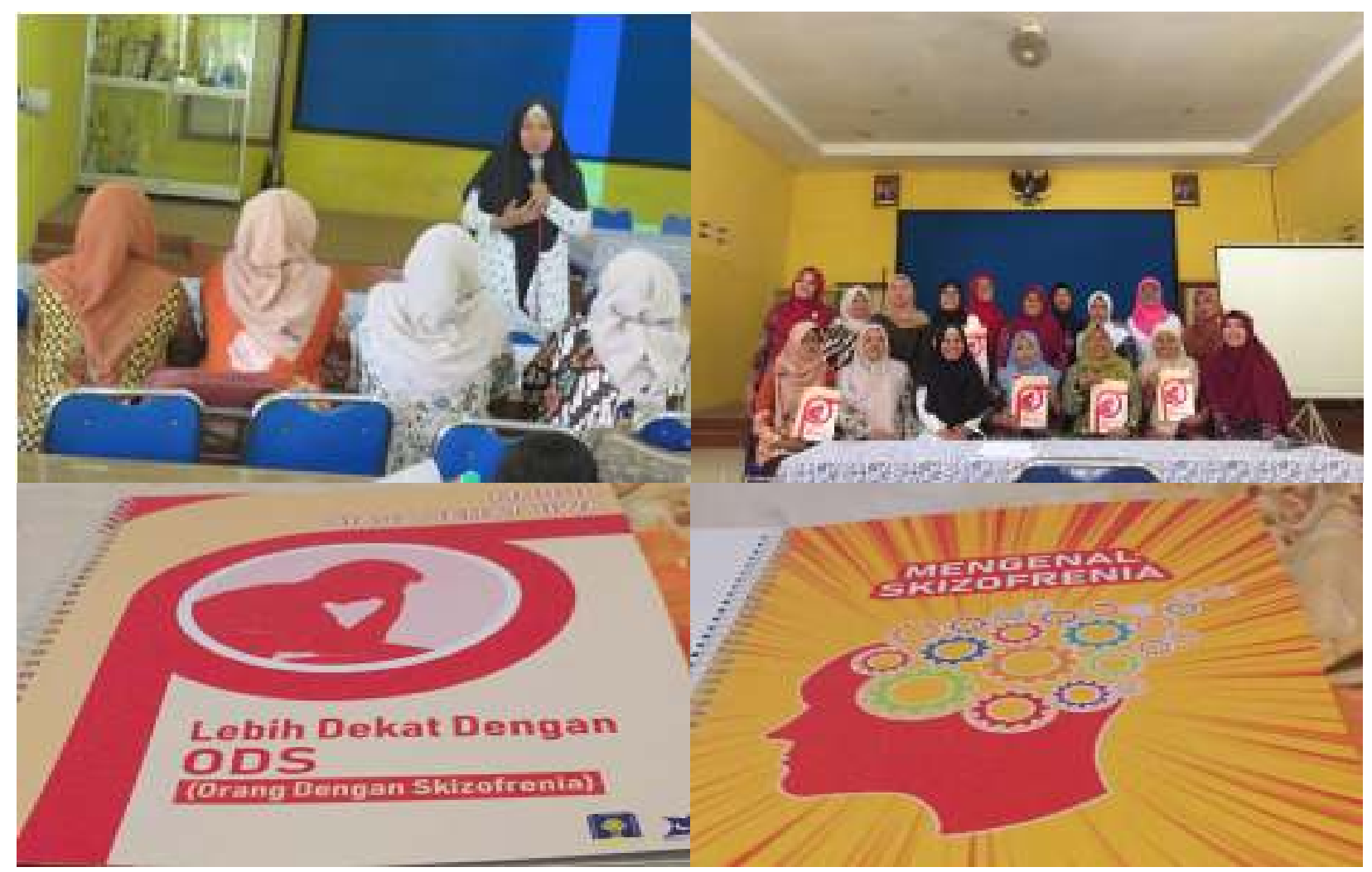

Gambar 2. Edukasi dan Penunjukan Kader Siaga Sehat Jiwa 


\section{HASIL DAN PEMBAHASAN}

Pencapaian hasil kegiatan ini dirancang untuk bisa meningkatkan pengetahuan atau literasi masyarakat terhadap skizofrenia dan bagaimana seharusnya berinteraksi secara sosial dengan pengidapnya. Pada gilirannya, peningkatan pengetahuan masyarakat akan skizofrenia diharapkan dapat merubah sikap dan perlakuan mereka terhadap ODS. Dengan begitu, upaya untuk menguatkan kognisi sosial pada ODS bisa berjalan dengan lebih baik mengingat adanya dukungan dari lingkungan sekitarnya.

Dalam mengukur pencapaian ini, digunakan kuesioner untuk mengukur peningkatan pengetahuan peserta yang mengikuti penyuluhan (indikator dalam kuesioner bisa dilihat di Tabel 1). Peserta diminta mengisi kuesioner sebelum dan sesudah penyuluhan. Peserta yang dapat menjawab benar sedikitnya 10 pernyataan dikategorikan sebagai peserta dengan pengetahuan skizofrenia tinggi, dan peserta yang tidak dapat menjawab benar sedikitnya lima pernyataan dikategorikan sebagai peserta dengan pengetahuan skizofrenia rendah.

Tabel 1 Indikator pengukuran literasi skizofrenia

\begin{tabular}{|l|l|l|l|}
\hline No & Pernyataan & Ya & Tidak \\
\hline 1 & Penyakit skizofrenia (gangguan jiwa) dapat disebabkan oleh keturunan. & & \\
\hline 2 & Penyakit skizofrenia dapat disebabkan oleh gangguan mahluk halus. & & \\
\hline 3 & Penyakit skizofrenia dapat menular. & & \\
\hline 4 & Penyakit skizofrenia dapat disembuhkan. & & \\
\hline 5 & Penyakit skizofrenia umumnya muncul pada usia dewasa. & & \\
\hline 6 & Halusinasi adalah salah satu gejala dari skizofrenia. & \\
\hline 7 & Mengurung diri adalah salah satu gejala dari skizofrenia. & \\
\hline 8 & Pemasungan pada penderita skizofrenia adalah salah satu terapi untuk & \\
\hline 9 & penyembuhan. & & \\
\hline 10 & Pengobatan spiritiual dapat menyembuhkan skizofrenia. & & \\
\hline 11 & Obat-obatan untuk skizofrenia dapat menyebabkan ketergantungan. & \\
\hline
\end{tabular}

Tabel 2 merangkum data peserta dan tingkat responsi pengisian serta hasil rekapitulasi atas isian peserta. Dari Tabel 2 terlihat adanya peningkatan pengetahuan akan skizofrenia baik pada anggota keluarga ODS maupun anggota keluarga non-ODS. Untuk anggota keluarga ODS, ada 15 orang yang hadir (termasuk di dalamnya ODS) dan 10 orang di antaranya mengisi kueisoner secara lengkap.

Tabel 2 Hasil olah data pengetahuan skizofrenia

Tingkat pengetahuan

Anggota keluarga ODS

Sebelum penyuluhan

Setelah penyuluhan 
JAMALI - Volume. 01, Issue. 02, September 2019

\begin{tabular}{|l|l|l|} 
Pengetahuan rendah & 8 & 1 \\
\hline Pengetahuan tinggi & 2 & 9 \\
\hline Yang mengisi kuesioner & 10 & 10 \\
\hline Yang hadir saat acara & 15 & 15 \\
\hline Tingkat pengetahuan & Non-anggota keluarga ODS \\
\cline { 2 - 3 } & Sebelum penyuluhan & Setelah penyuluhan \\
\hline Pengetahuan rendah & 8 & 2 \\
\hline Pengetahuan tinggi & 0 & 6 \\
\hline Yang mengisi kuesioner & 8 & 8 \\
\hline Yang hadir saat acara & 10 & 10 \\
\hline
\end{tabular}

Dari 10 orang tersebut, sebelum pelatihan $80 \%$ di antaranya memiliki pengetahuan rendah dan $20 \%$ sisanya berpengatahuan tinggi terkait skizofrenia. Setelah penyuluhan, terjadi peningkatan pengetahuan zkizofrenia dari yang semula $20 \%$ berpengetahuan tinggi jadi $90 \%$ berpengetahuan tinggi (lihat Gambar 3).
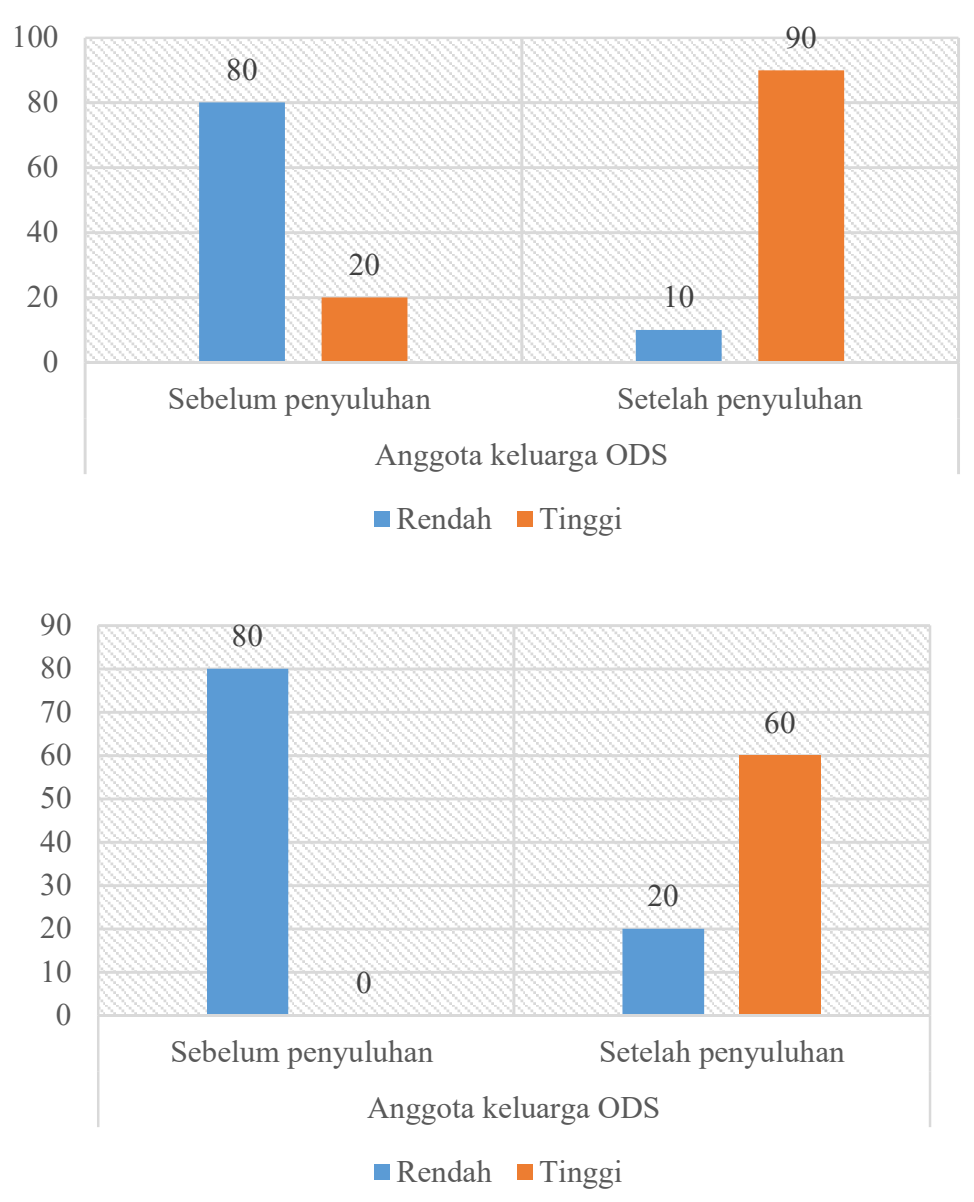

Gambar 3. Grafik peningkatan pengetahuan skizofrenia pasca penyuluhan 
Hal yang sama terjadi pada anggota keluarga non-ODS yang mengikuti penyuluhan. Dari 10 orang yang hadir, 8 di antaranya mengisi kuesioner secara lengkap. Hasil pengolahan data menunjukkan adanya peningkatan pengetahuan tinggi sebesar $60 \%$ dibandingkan sebelum penyuluhan yang hanya $0 \%$.

Dari hasil pengolahan data di atas dapat ditarik kesimpulan adanya peningkatan pengetahuan masyarakat terhadap skizofrenia. Meskipun yang menghadiri penyuluhan hanya sebagian dari anggota masyarakat yang diundang, namun hasil ini menjadi penting mengingat anggota masyarakat di desa bisa menjadi perantara transfer pengetahuan satu sama lain karena masih eratnya tali kebersamaan antar anggota masyarakat. Di samping itu, dibentuknya kader siaga sehat jiwa juga diharapkan bisa menjadi stimulus perubahan interksi sosial ODS dengan lingkungannya.

Untuk mengukur keberhasilan capaian dibentuknya kader siaga sehat jiwa ini, tim melakukan komunikasi secara langsung kepada anggota keluarga ODS dan mengkonfirmasi apakah ada perubahan sikap dari lingkungan terhadap ODS pasca adanya penyuluhan dan dibentuknya kader siaga sehat jiwa. Daari informasi yang tim dapatkan, terinformasi bahwa pola inklusi sosial masyarakat menjadi lebih baik terhadap anggota keluarganya yang ODS dan anggota keluarga mereka yang ODS juga dianggap lebih terbuka untuk berinteraksi dengan lingkungan sekitarnya. Dua bulan sejak diselenggarakannya acara penyuluhan dan pembentukan kader siaga, anggota keluarga ODS juga melaporkan menurunnya prevalensi gejala seperti menyendiri yang biasanya yang ditunjukkan oleh anggota keluarga mereka yang ODS.

Hasil ini didukung oleh penelitian Suryani, Ningsih dan Nur'aeni (2019) yang menyatakan bahwa sangat penting bagi tenaga kesehatan untuk selalu meningkatkan informasi dan pengetahuan tentang penyakit skizofrenia. Pengetahuan yang baik akan skizofrenia oleh anggota keluarga akan meningkatkan dukungan keluarga dan akhirnya akan dapat menguatkan kognisi sosial ODS (Latipun, 2016).

\section{SIMPULAN}

Rangkaian kegiatan dalam program pengabdian ini mampu meningkatkan literasi masyarakat, baik anggota keluarga ODS maupun anggota keluarga non-ODS, akan skizofrenia dan berbagai karakteristiknya yang melekat pada ODS. Peningkatan literasi ini tampaknya mampu mengubah sikap dan perilaku lingkungan terhadap ODS sehingga bisa memperkuat kognisi sosial dan menekan tingkat kekambuhan pada ODS.

Ada beberapa kendala utama yang dijumpai saat penyelenggaraan kegiatan. Pertama, tidak semua ODS dapat mengikuti rangkaian kegiatan secara penuh. Para ODS yang tidak mengikuti rangkaian kegiatan ini salah satunya disebabkan karena status mereka yang menurut anggota keluarga tidak stabil dan masih aktif. Kedua, tidak terlalu banyaknya masyarakat non-ODS yang dapat mengikuti penyuluhan meskipun kepala desa telah mengambil waktu yang cukup untuk melakukan sosialisasi.

Capaian dari diselenggarakannya kegiatan ini seyogyanya menjadi upaya awal pemberdayaan ODS yang bisa diikuti oleh upaya pemberdayaan lainnya di masa mendatang. Selain keberdayaan sosial, ODS umunya juga mengalami masalah dalam hal keberdayaan ekonomi. Padahal, beberapa penelitian terbaru mengkonfirmasi bahwa ODS pada dasarnya mampu bekerja sebagaimana anggota mayarakat lainnya. Oleh karena itu, ke depan perlu dibuat tindak lanjut kegiatan dalam rangka mempeberdayakan ODS secara ekonomi. Upaya yang bisa dilakukan di antaranya dengan menggunakan terapi vokasional dimana ODS diberikan peluang 
JAMALI - Volume. 01, Issue. 02, September 2019

untuk berusaha secara mandiri. Dengan begitu, upaya pemberdayaan ODS dapat dilakukan secara lebih komprehensif dan berkesinambungan.

\section{UCAPAN TERIMA KASIH}

Ucapan terimakasih kami sampaikan kepada DRPM Kemenristek Dikti yang telah mendanai program ini. Ucapan terimakasih juga kami sampaikan kepada seluruh Direktorat Penelitian dan Pengabdian Masyarakat (DPPM) UII, serta jajaran pemerintah Desa Sindumartani yang telah berkerjasama dengan kami sehingga program ini bisa terlaksana dengan baik.

\section{DAFTAR PUSTAKA}

Awad, A. G. (2016) Beyond Assessment of Quality of Life in Schizophrenia. Edited by A. G. Awad and L. N. P. Voruganti. Switzerland: Springer International Publishing.

Badan Penelitian dan Pengembangan Kesehatan Kementerian Kesehatan (2018) Hasil Utama Riset Kesehatan Dasar 2018. Jakarta.

Fernando, S. M. et al. (2017) 'Asian pearls A carer burden and stigma in schizophrenia and affective disorders : Experiences from Sri Lanka', Asian Journal of Psychiatry. Elsevier B.V., 26, pp. 77-81. doi: 10.1016/j.ajp.2017.01.023.

Fulford, D., Campellone, T. and Gard, D. E. (2018) 'Social motivation in schizophrenia : How research on basic reward processes informs and limits our understanding', Clinical Psychology Review. Elsevier, 63(May), pp. 12-24. doi: 10.1016/j.cpr.2018.05.007.

Human Rights Watch (2016) Hidup di Neraka: Kekerasan terhadap Penyandang Disabilitas Psikososial di Indonesia. Amerika Serikat.

Krupchanka, D. et al. (2018) 'Experience of stigma and discrimination in families of persons with schizophrenia in the Czech Republic', Social Science \& Medicine, 212(2), pp. 129-135. doi: 10.1016/j.socscimed.2018.07.015.

Langdon, R., Connors, M. H. and Connaughton, E. (2014) 'Cognition Social cognition and social judgment in schizophrenia', Schizophrenia Research: Cognition. The Authors, 1(4), pp. 171-174. doi: 10.1016/j.scog.2014.10.001.

Latipun, F. S. (2016) 'Hubungan Dukungan Keluarga dan Keberfungsian Sosial pada Pasien Skizofrenia Rawat Jalan', Jurnal Ilmiah Psikologi Terapan, 04(02), pp. 140-160.

Levine, J. and Levine, I. S. (2009) Schizophrenia for Dummies. Indiana: Wiley Publishing.

Li, J. et al. (2017) 'Stigma and discrimination experienced by people with schizophrenia living in the community in Guangzhou, China', Psychiatry Research. Elsevier Ireland Ltd, 255(36), pp. 225-231. doi: 10.1016/j.psychres.2017.05.040.

Mcnally, K. (2016) A Critical History of Schizophrenoa. 1st edn. Hampshire: Palgrave Macmillan.

Morgades-bamba, C. I., Fuster-ruizdeapodaca, M. J. and Molero, F. (2019) 'The impact of internalized stigma on the well-being of people with Schizophrenia', Psychiatry Research. Elsevier Ireland Ltd, 271(October 2018), pp. 621-627. doi: 10.1016/j.psychres.2018.12.060.

Reddy, L. F. et al. (2019) 'Social exclusion in schizophrenia: Psychological and cognitive consequences', 
Abdur Rafik ${ }^{1 *}$, Febrianti $^{2}$,Lusiyana ${ }^{3}$

Journal of Psychiatric Research. Elsevier, 114(August 2018), pp. 120-125. doi: 10.1016/j.jpsychires.2019.04.010.

Simanullang, R. H. (2018) 'The Correlation between Family Support and Relapse in Schizophrenia at The Psychiatric Hospital', Belitung Nursing Journal, 4(6), pp. 566-571.

Suryani, Ningsih, E. W. and Nur'aeni, A. (2019) 'Knowledge, Perception, and Burden of Family in Treating Patients with Schizophrenia who Experience Relapse', Belitung Nursing Journal, 5(4), pp. 162-168.

Zahnia, S. and Sumekar, D. W. (2016) 'Kajian Epidemiologis Skizofrenia', Majority, 5(5), pp. 161-166. 